\title{
Improving the Quality of Human Resources in Ciburuy Village Staff to Improve the Quality of Public Services
}

\author{
Deden Ardiansyah ${ }^{\mathrm{a}}$, Salmah $^{\mathrm{a} *}$ \\ ${ }^{a}$ Universitas Pakuan, Bogor, Tegallega, Bogor, 16129, Indonesia \\ Corresponding author e-mail address: ardiansyahdeden@unpak.ac.id
}

\begin{abstract}
Utilization of computer technology to improve the quality of public services in Ciburuy village cannot be carried out optimally if it is not supported by the readiness of human resources as the parties who use it. readiness of human resources in using computer technology is one of the important factors in terms of public services. Therefore we need a computer technology transfer process that is adequate, right on target and appropriate for Ciburuy village staff, as the main actor in this activity, namely service to the community. Methods of implementing human resource improvement through computer skills training activities through the Microsoft Word Application Program, Microsoft Excel, Microsoft Power Point, databases and networks are carried out through several stages. resulting in an average value of being satisfied and quite satisfied so that public services in Ciburuy village must improve service quality. but the unique thing is seen in the ability of village staff in the service. so that respondents have started to feel satisfied with the services carried out by Ciburuy village staff.
\end{abstract}

Keywords: Service,Public, quality,computer,technology.

\section{Introduction}

Utilization of computer technology to improve the quality of public services in Ciburuy village cannot be carried out optimally if it is not supported by the readiness of human resources as the parties who use it. readiness of human resources in using computer technology is one of the important factors in terms of public services. so that technological progress can be directly proportional to the quality of 
service.(Boon-itt, 2015; Lowry \& Wilson, 2016) by utilizing computer technology can have a possitife effect on service quality such as speeding up service, providing convenience to users and reducing labor costs.(Alijani, Fulk, Omar, \& Tulsi, 2014).

Therefore we need a computer technology transfer process that is adequate, right on target and appropriate for Ciburuy village staff, as the main actor in this activity, namely service to the community. service to the community is still carried out in a conventional manner without using a simple database or a simple computer network so that every existing computer device is not mutually integrated which results in the service process at the Ciburuy village office being very slow. therefore, technology transfer is needed so that the Ciburuy village staff can serve the community well.(Kuo \& Tang, 2013; Sumaedi \& Yarmen, 2015)

The technology transfer is intended through a Basic Computer Application Technology Training for businesses for Ciburuy Village staff in Cigombong District. The results of questionnaires / questionnaires about the need for basic computer application skills for businesses for staff members of Ciburuy Village, in weekly meetings at the village office revealed that of the 15 personnel present, namely the Village Head and village staff, most respondents were unable to operate business computer applications integrated with a simple database and a simple computer network around $90 \%$.

Based on this, it can be concluded that staff members of Ciburuy Village cannot use and operate computer applications for business. To support this, training on basic computer program applications for businesses such as ms.word, ms.excell, Power point, database and computer networks is needed to support administrative activities of village staff in terms of service improvement (Tosida et al., 2012; 2020).

Utilization of computer technology to improve the quality of village office services cannot be carried out optimally if it is not supported by the readiness of human resources as the parties who use it. Therefore, a computer technology transfer process that is adequate, right on target and appropriate for village staff as the main actor in this activity is needed. The technology transfer is intended through a Basic Computer Application Technology Training for businesses for Ciburuy Village staff in Cigombong District. so that this training activity can improve the quality of services performed at the Ciburuy village office. (Dabholkar, 2015; Moumane, Idri, \& Abran, 2016)

\section{Materials and Methods}

\subsection{Materials}

Service quality has been conceptualized as an overall assessment of service by the customers, services that are assisted with technology can provide convenience and speed to the public services provided but the technology requires adequate human resources to run it. Therefore, it is necessary to transfer knowledge to public servants to be able to use technology properly and correctly to provide excellent service. the previous literature clearly highlights that there are many studies on the dimensions of service quality associated with conventional services and activated technology. (Ganguli \& Roy, 2010)

The core of public service is the attitude of being helpful, friendly and professional in providing services or products from a certain agency that satisfy the society. Public service demands of each element in the agency to empathise with the public (Ardiansyah et al., 2020). It implies a certain meaning; as the ability of government bureaucrats to put themself on the community and comprehend the things or issues from a community perspective. Performance as a term, means the final result of an activity in carrying out job responsibilities as efficiently and effectively as possible. Managers need to understand that the concept of "Organizational Performance " is the final result of the accumulation of all the working processof the organization and he/she needs to understand the factors that lead to high performance on the organization.(Hadiyati, 2014) 
According to the Decree of the Minister of State for Administrative Reform Number: 63 / KEP / M.PAN / 7/2003 that every public service should have a standard of service and be published as a guarantee of certainty for service users. The standard of service is a measure that is standardised in public service that must be obeyed by the party who delivers and uses the service. Minimum service standards cover:

1. Procedure of service Standardised procedures for service providers and recipients of services including complaints.

2. Solution time The time which is allocated from the time of submission of the applicant until the completion of the service, including complaints.

3. Cost of services Costs or tariffs which include the detail that has been set in the service.

4. Products of services The results of the services which will be received in line with the regulation conditions.

5. Facilities and infrastructure The provision of facilities and infrastructure which is adequate by the public service providers.

6. Competence of personnel service providers Competence of personnel service providers should be set appropriately based on requirement of knowledge, expertise, skills, attitudes and behaviors.

\subsection{Methods}

Methods of implementing human resource improvement through computer skills training activities through the Microsoft Word Application Program, Microsoft Excel, Microsoft Power Point, databases and networks are carried out through several stages as shown in Figure 1, namely:

1. The training will be held at the Ciburuy village office. The training activities will be carried out within 4 (four) days. The results of the training are in the form of personal skills of village officials,

2. The initial stage of training is the introduction of computer technology through tutorial activities. The initial material is an explanation of the main components of a computer as an Input-ProcessOutput system. In this activity participants were introduced to input devices / devices in the form of keyboards, process tools / devices in the form of CPUs and their specifications and output devices / devices in the form of monitors, printers and speakers.

3. The second stage of training is training in the Microsoft Word Application Program. The method of applying science and technology is done through a combination of tutorials and hands-on labs. At this stage, it is explained and practiced about the ability of the program as a tool in completing tasks: archiving management, document typing, document editing, letter formatting, data tabulation, printing, and trouble shoting.

4. The third stage of training is training in the Microsoft Excel Application Program. The method of applying science and technology is done through a combination of tutorials and hands-on labs. At this stage, it is explained and practiced about the ability of the program as a tool in completing tasks: data tabulation, utilization of sort ascending-discending menus, utilization of mathematical menus for computerized calculations and making graphical displays and data (diagrams) rods, polygons, scaters, and pie / cake diagrams), as well as trouble shoting.

5. The fourth stage of training is training in the Microsoft Powerpoint Application Program. The method of applying science and technology is done through a combination of tutorials and handson labs. At this stage, it is explained and practiced about the ability of the application program as a 
tool in completing the work of presentation materials with an attractive, representative and attractive appearance.

6. Ciburuy village staff is able to implement the results of training on public services conducted.

7. The final stage of the training is measuring the ability of the training results and service quality measurement by method.

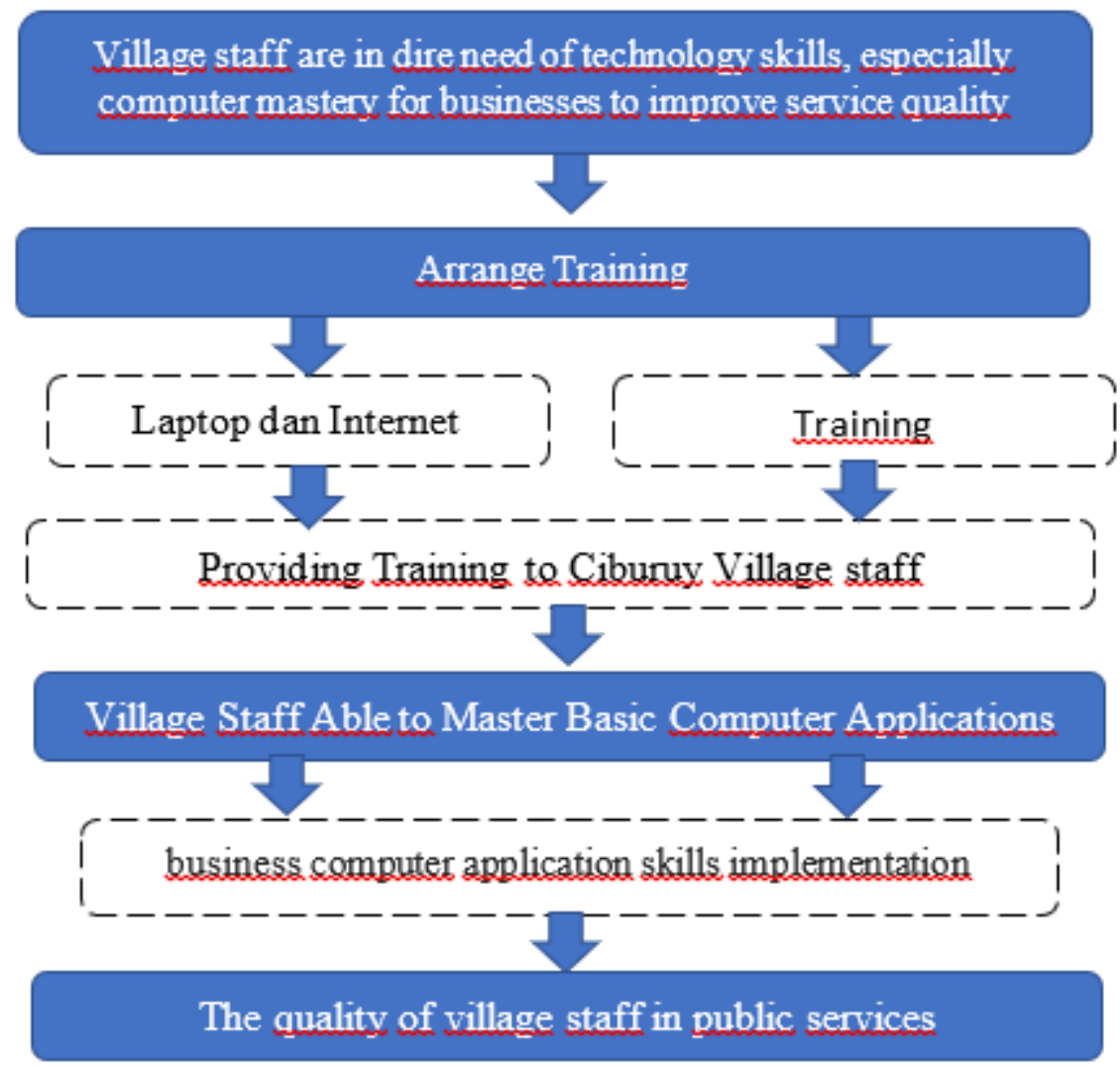

Figure 1 Transfer Technology Methode

\section{Results and Discussion}

The results of this training activity is that each staff can understand the material that has been delivered and can practice the results of staff administration work such as making letters, attendance and minutes of meetings, calculations using Microsoft Excel simple and make a percentage, troubleshoot a broken computer. each training participant is able to implement the results of the training activities with services that exist in Ciburuy village office.

Tabel 1 Result Of Training

\begin{tabular}{|l|r|r|r|r|}
\hline & Very Capable & Capable & quiet Capable & Not Capable \\
\hline Word & 8 & 5 & 2 & 0 \\
\hline Excel & 6 & 5 & 4 & 0 \\
\hline
\end{tabular}




\begin{tabular}{|l|l|l|l|l|}
\hline Powerpoint & 7 & 8 & 0 & 0 \\
\hline Database & 3 & 5 & 6 & 1 \\
\hline Jaringan & 4 & 3 & 6 & 2 \\
\hline
\end{tabular}

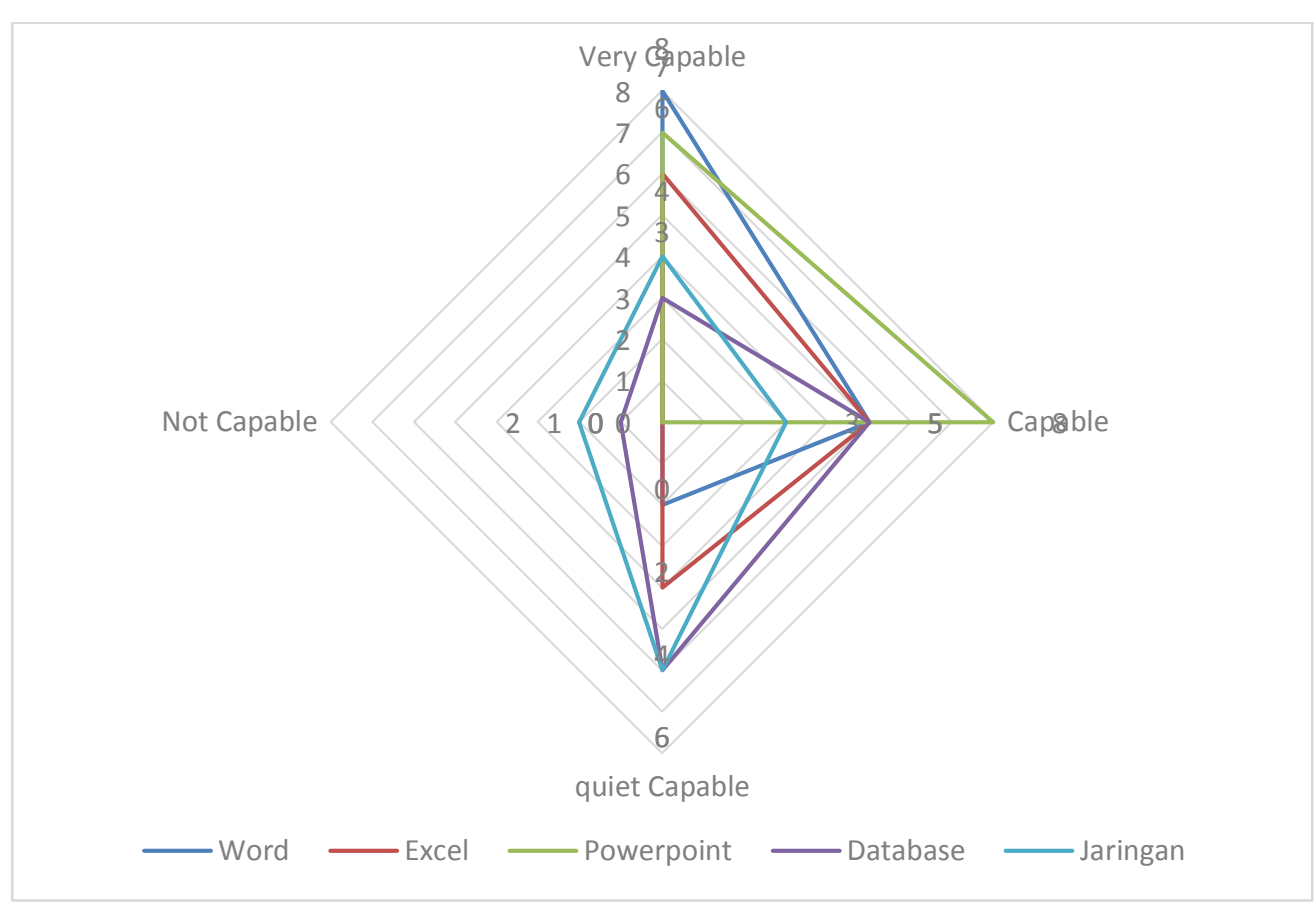

Figure 2 Result Of Training

Of the 15 village staff participating in the training activities, almost all village staff were able to participate and were able to implement all the materials received at the time of the training. this can be seen from the results of the questionnaire and assessment conducted by the trainer with the results as in table 1 and figure 2 . these results are good results for a training activity. the training activity will be successful if the trainer also gives the material well, therefore, the researcher gives a questionnaire to the participants about the training. 


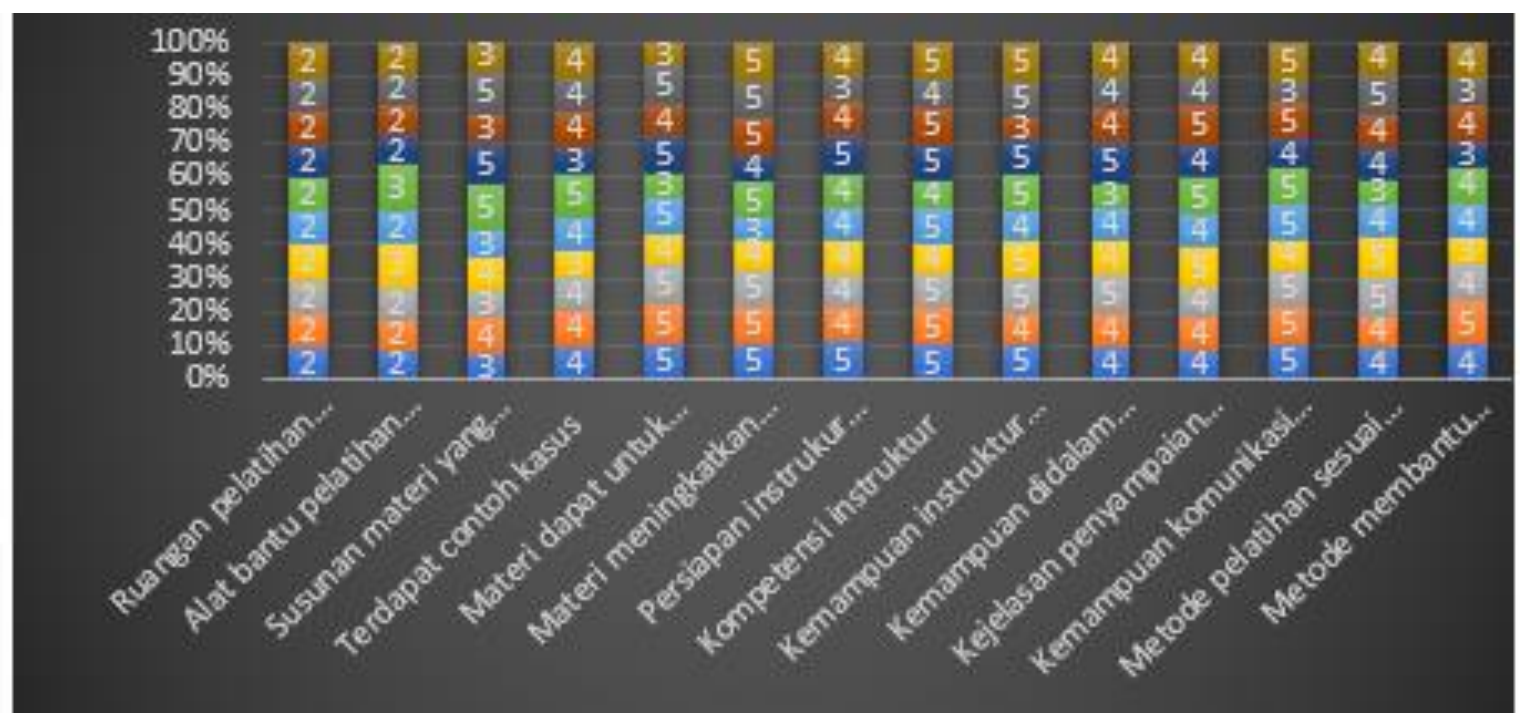

Figure 3 Training Methode

The method used helps the absorption of the material by the participants, this is shown by the assessment of trainees who on average give a score of 4 which is an important criterion. training methods in accordance with the material, the participants gave an average rating of 4.5 , this shows the training is very suitable with the training method verbal communication skills of trainers with participants is very important because they say good communication is a major component that must be possessed by the instructor to deliver the material. the clarity of the delivery of material by the instructor is very important and very good, evidenced by the results obtained from the training.

The instructor's ability to answer participant's questions, in this case getting an average rating of 4 , thus the instructor's ability to answer participant's questions is an important part of supporting training the instructor's competence in providing training shows that the assessment of the average participant answers 5, this shows the instructor's competence is very important in carrying out the training, the instructor's preparation in bringing training material is one of the important indicators during running the training so that the training material can be well delivered by participants and material suitability that increases knowledge and abilities is very important especially in administrative services in the Ciburuy village environment (Tosida et al., 2017; 2018).

After evaluating the results of the final training phase, which is evaluating the effect of the results of activities owned by the Ciburuy village staff, does it affect the quality of public services carried out. service quality assessment is measured according to the Minister of State for Administrative Reform Number: 63 / KEP / M.PAN / 7/2003 on point 6 namely Competence of personnel service providers Competence of personnel service providers should be set appropriately based on requirements of knowledge, expertise , skills, attitudes and behaviors. The assessment was carried out by survey method with 150 respondents grouped according to age, namely age 45-60 years, 30-45 years and 17-30 years. the age grouping is done to find out the quality of service based on knowledge, expertise , skills, attitudes and behaviors on each group of 50 respondents. result can shown in figure 4. 


\section{Result Measurement Service Quality}

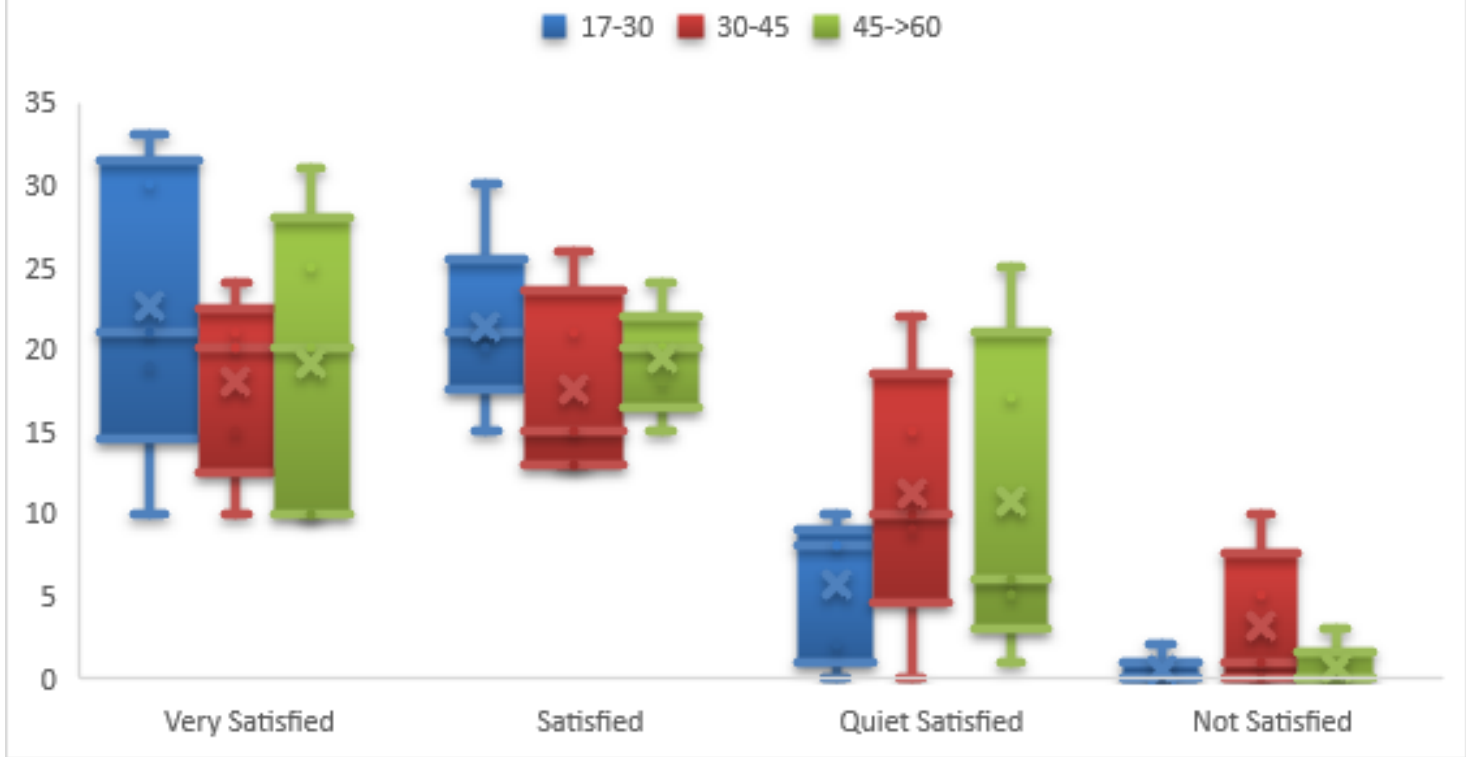

Figure 4 Result Measurement Service Quality

In Figure 4, the measurement results show that each respondent has begun to feel satisfied with public services, resulting in an average value of being satisfied and quite satisfied so that public services in Ciburuy village must improve service quality. but the unique thing is seen in the ability of village staff in the service. so that respondents have started to feel satisfied with the services carried out by Ciburuy village staff.

\section{Conclussion}

Based on this, it can be concluded that staff members of Ciburuy Village cannot use and operate computer applications for business. To support this, training on basic computer program applications for businesses such as ms.word, ms.excell, Power point, database and computer networks is needed to support administrative activities of village staff in terms of service improvement. Utilization of computer technology to improve the quality of village office services cannot be carried out optimally if it is not supported by the readiness of human resources as the parties who use it. Methods of implementing human resource improvement through computer skills training activities through the Microsoft Word Application Program, Microsoft Excel, Microsoft Power Point, databases and networks are carried out through several stages and The results of this training activity is that each staff can understand the material that has been delivered and can practice the results of staff administration work such as making letters, attendance and minutes of meetings, calculations using Microsoft Excel simple and make a percentage, troubleshoot a broken computer. Resulting in an average value of being satisfied and quite satisfied so that public services in Ciburuy village must improve service quality. but the unique thing is seen in the ability of village staff in the service. so that respondents have started to feel satisfied with the services carried out by Ciburuy village staff. 


\section{Acknowledgments}

Acknowledgments need to be delivered to Pakuan University Research and Community Service Institute.

\section{References}

Ardiansyah, D., Tosida, E.T., Waluyo, A.D. (2020). Optimization of Accounting Information System Reiinforcing of Tourism Based Small and Medium Enterprises (SMEs) : International Journal of Scientific \& Technology Research, Vol 9 Issue 03, March 2020, pp 1282-1286

Alijani, G. S., Fulk, H. K., Omar, A., \& Tulsi, R. (2014). Cloud computing effects on small business. Entrepreneurial Executive.

Boon-itt, S. (2015). Managing self-service technology service quality to enhance e-satisfaction. International Journal of Quality and Service Sciences. https://doi.org/10.1108/IJQSS-01-2015-0013

Dabholkar, P. A. (2015). How to Improve Perceived Service Quality by Increasing Customer Participation. https://doi.org/10.1007/978-3-319-13254-9_97

Ganguli, S., \& Roy, S. K. (2010). Service quality dimensions of hybrid services. Managing Service Quality: An International Journal. https://doi.org/10.1108/09604521011073713

Hadiyati, E. (2014). Service Quality and Performance of Public Sector: Study on Immigration Office in Indonesia. International Journal of Marketing Studies. https://doi.org/10.5539/ijms.v6n6p104

Kuo, C. W., \& Tang, M. L. (2013). Relationships among service quality, corporate image, customer satisfaction, and behavioral intention for the elderly in high speed rail services. Journal of Advanced Transportation. https://doi.org/10.1002/atr.179

Lowry, P. B., \& Wilson, D. (2016). Creating agile organizations through IT: The influence of internal IT service perceptions on IT service quality and IT agility. Journal of Strategic Information Systems. https://doi.org/10.1016/j.jsis.2016.05.002

Moumane, K., Idri, A., \& Abran, A. (2016). Usability evaluation of mobile applications using ISO 9241 and ISO 25062 standards. SpringerPlus. https://doi.org/10.1186/s40064-016-2171-z

Sumaedi, S., \& Yarmen, M. (2015). Measuring Perceived Service Quality of Fast Food Restaurant in Islamic Country: A Conceptual Framework. Procedia Food Science. https://doi.org/10.1016/j.profoo.2015.01.012

Tosida, E.T., Wahyudin, I., Andria, F., Djatna, T., Ningsih, W.K., \& Lestari, D.D. (2020). Business Intelligence of Indonesian Telematics Human Resource : Optimizing of Customer and Internal Balanced Scorecards. Journal of Southwest Jiaotong University, Vol. 55 No. 2, Apr (2020). DOI : 10.35741/issn.0258-2724.55.2.7.

Tosida, E.T., P Harsani, \& Setyaningsih, S. (2012). Classification Models of Information Technology Services Bussiness in Indonesia. Proceeding Internasional Seminar on Science and Technology Innovations 2012.

Tosida E.T., Maryana, S., \& Thaheer, H. (2017). Implementation of Self Organizing Map (SOM) as decision support : Indonesian telematics services MSMEs empowerment. IOP Conference Series : Materials Science and Engineering, 166 (1), 012017.

Tosida E.T, Hairlangga, O., Amirudin, F., \& Ridwanah, M. (2018). Application of Decision Rules for Empowering of Indonesian Telematic Services SMEs. IOP Conference Series : Materials Science and Engineering. 332 (1), 012018. 